\title{
WILLINGNESS TO PAY KONSUMEN BERAS ORGANIK DAN FAKTOR-FAKTOR YANG BERKAITAN DENGAN KESEDIAAN KONSUMEN UNTUK MEMBAYAR LEBIH
}

\author{
Yulia Sari1), Elly Rasmikayati2), Bobby Rachmat Saefudin'3), Tuti Karyani4), \\ dan Sulistyo Dewi5) \\ 1, 2, 4, 5)Program Studi Agribisnis, Fakultas Pertanian, Universitas Padjajaran \\ Jl. Raya Bandung Sumedang KM.21, Kec. Jatinangor, Kab. Sumedang, Jawa Barat, Indonesia \\ 3)Program Studi Agribisnis, Fakultas Pertanian, Ma'soem University \\ Jl. Raya Cipacing No. 22, Kec. Jatinangor, Kab. Sumedang, Jawa Barat, Indonesia \\ 1)e-mail: elisarnf@gmail.com
}

(Diterima 22 Januari 2020 / Disetujui 10 Februari 2020)

\begin{abstract}
Increased public concern and awareness of health and environment, is expected to significantly increase organic rice consumers. Thus, it can be consumed and reached by more people. The objectives of the study were to identify the characteristics of organic rice consumers, measure willingness to pay of organic rice consumers and analyze the factors related to the willingness to pay of organic rice consumers. The method used in this study is a survey method with descriptive statistical analysis and Contingent Valuation Method (CVM). The numbers of research respondents were 51 people consisting of organic rice consumers in Warung Sehat 1000 Kebun (W1000K) as much 18 people and consumers of organic rice in several other places joined in the Indonesian Organic Community as much 33 people. The results showed that consumers were willing to pay up to $10 \%$ higher than the price offered for organic rice type of pandan wangi, menthik susu, red rice and brown rice sold in W1000K. Even in some other places, consumers are willing to pay for those rice at prices higher up to $22 \%$ of the offered price. While for organic rice type of black rice, consumers are willing to pay 9\%-11\% lower than the price offered. Factors related to consumers' willingness to pay more for organic rice are health (67\%), food security (45\%), impact on the environment (43\%), knowledge of organic rice (39\%), easy access to get rice (37\%), service (33\%), quality (25\%), packaging (24\%), price (20\%), and lifestyle (18\%).
\end{abstract}

Keywords: contingent valuation method, consumer, factors, healthy rice, organic rice, rice price, willingness to pay

\begin{abstract}
ABSTRAK
Bertambahnya kepedulian dan kesadaran masyarakat terhadap kesehatan dan lingkungan, diharapkan mampu meningkatkan konsumen beras organik secara signifikan sehingga dapat dikonsumsi dan dijangkau oleh lebih banyak lagi kalangan masyarakat. Penelitian ini bertujuan untuk mengidentifikasi karakteristik konsumen beras organik, mengukur kesediaan untuk membayar dari konsumen beras organik dan menganalisis faktor-faktor yang berkaitan dengan kesediaan membayar konsumen beras organik. Metode yang digunakan dalam penelitian ini adalah metode survey dengan alat analisis statisik deskriptif dan Contingent Valuation Method (CVM). Responden penelitian sebanyak 51 orang yang terdiri dari konsumen beras organik di Warung Sehat 1000 Kebun (W1000K) sebanyak 18 orang dan konsumen beras organik di beberapa tempat lain yang tergabung dalam Komunitas Organik Indonesia sebanyak 33 orang. Hasil penelitian menunjukan bahwa konsumen bersedia membayar lebih tinggi hingga $10 \%$ dari harga yang ditawarkan untuk beras organik jenis beras pandan wangi, beras menthik susu, beras merah, beras coklat yang dijual di W1000K. Bahkan di beberapa tempat lain, konsumen bersedia membayar beras-beras tersebut dengan harga yang lebih tinggi hingga $22 \%$ dari harga yang ditawarkan. Sedangkan untuk beras organik jenis beras hitam, konsumen justru bersedia membayar lebih rendah 9\%-11\% dari harga yang ditawarkan. Faktor-faktor yang berkaitan dengan kesediaan konsumen untuk membayar lebih terhadap beras organik adalah faktor kesehatan (67\%), keamanan pangan (45\%), dampak terhadap lingkungan (43\%), pengetahuan mengenai beras organik (39\%), kemudahan akses dalam mendapatkan beras (37\%), pelayanan (33\%), kualitas beras (25\%), kemasan beras (24\%), harga (20\%), dan gaya hidup (18\%).
\end{abstract}

Kata Kunci: beras organik, beras sehat, faktor-faktor, harga beras, kesediaan untuk membayar, konsumen 


\section{PENDAHULUAN}

Pasar global untuk produk organik mengalami peningkatan dari $\$ 38,6$ miliar pada tahun 2006 menjadi \$71 miliar pada tahun 2008 dan menjadi \$83,21 miliar pada 2015 dengan konsumen terbanyak berada di Amerika Utara sebanyak €107,7 konsumsi per kapita dan Eropa $€ 36,4$ kosumsi per kapita (FIBL \& International, 2017). Disamping itu, luas lahan pertanian organik di dunia juga meningkat setiap tahunnya (Gambar 1).

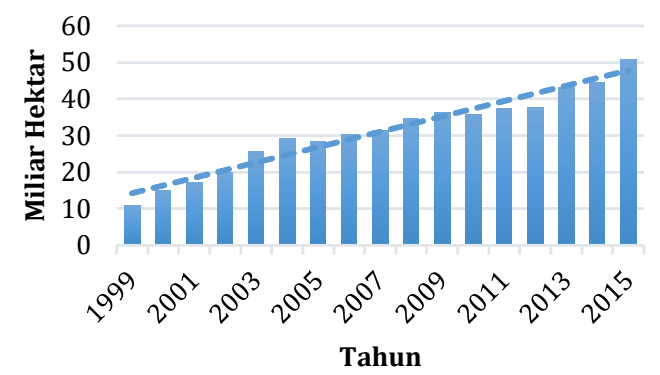

\section{Gambar 1. Pertumbuhan Lahan Pertanian Organik di Dunia Tahun 1999-2015 Sumber: FIBL \& International (2017)}

Meningkatnya luasan lahan pertanian organik di dunia berbanding lurus dengan peningkatan lahan pertanian di Indonesia. Pertumbuhan lahan pertanian organik di Indonesia mengalami peningkatan dari tahun 2012 hingga 2015 (Tabel 1). Merujuk pada hasil kajian FIBL \& International (2017), Indonesia berada pada peringkat lima besar negara dengan luasan area organik terbesar tahun 2015 yaitu dengan luas 130.384 ha.

Tabel 1. Pertumbuhan Lahan Pertanian Organik di Indonesia Tahun 20122015

\begin{tabular}{ccc}
\hline Tahun & Luas Lahan (ha) & $\begin{array}{c}\text { Pertumbuhan dalam } \\
\text { Satu Tahun (\%) }\end{array}$ \\
\hline 2012 & 88.247 & - \\
2013 & 65.688 & -26 \\
2014 & 113.638 & 73 \\
2015 & 130.384 & 15 \\
\hline \multicolumn{2}{l}{ Sumber: https://www.organikworld.net/index.html }
\end{tabular}

Meningkatnya luas lahan pertanian organik tidak terlepas dari faktor konsumen yang menganggap bahwa produk organik memiliki kualitas yang lebih baik dibandingkan dengan produk pada umumnya. Pada tahun 2010, pemerintah Indonesia melalui kementrian pertanian mengeluarkan sebuah program bernama Go Organic sebagai bentuk dukungan terhadap pertanian organik karena dianggap lebih menguntungkan bagi kesehatan dan lingkungan, serta untuk pengembangan agribisnis ramah lingkungan. Program Go Organic memiliki dampak positif dalam perkembangannya, ditunjukan dengan meningkatnya luas lahan komoditas organik.

Beras organik yang berasal dari pertanian organik memiliki perbedaan dengan beras konvensional. Beras organik lebih menyehatkan dan aman untuk dikonsumsi karena tidak terdapat pencemaran bahan kimia yang dapat membentuk radikal bebas. Beras organik bebas dari bahan kimia yang terdapat dalam pupuk, pestisida, hormon, dan obat-obatan. Dalam budidayanya beras organik menggunakan bibit padi yang bebas dari rekayasa genetika dan pupuk yang berasal dari kotoran hewan maupun kompos. Selain itu, beras organik tidak mengandung bibit yang dihasilkan dari rekayasa genetika dan tidak memanfaatkan teknologi radiasi untuk mengawetkan produknya. Beras organik melewati proses alamiah dari mulai aspek budidaya hingga pengolahannya (Thio, 2012). Beras organik juga dianggap sebagai alternatif untuk memelihara lingkungan (Santoso \& Fitryani, 2016).

Besarnya manfaat yang ditawarkan oleh pertanian organik tidak serta merta menjadikan para petani beralih ke pertanian organik, hal tersebut sebagian besar dikarenakan biaya produksi produk organik lebih tinggi dibandingkan dengan produk konvensional (Gil, Gracia, \& Sanchez, 2001). Terdapat penelitian yang menunjukkan bahwa biaya produksi produk organik lebih tinggi dibandingkan dengan produk yang diproduksi secara konvensional (Barkley, 2002). Hal ini dikarenakan produk organik harus memenuhi kriteria organik dan harus disertifikasi oleh lembaga sertifikasi yang diakui. Proses sertifikasi ini masih dianggap menyusahkan oleh petani karena petani masih sulit untuk merubah kebiasaan mereka untuk tidak menggunakan zat sintetis. Selain itu, proses-proses tersebut membutuhkan biaya yang cukup mahal, sehingga biaya produksi dan harga produk organik menjadi mahal (Haghjou, 2013). 
Terdapat dua konsekuensi untuk perbedaan harga pangan organik dan konvensional. Pertama, konsumen tidak akan berfikir dua kali untuk kesehatan dan lingkungan mereka dan bersedia membayar harga yang lebih tinggi untuk menjaga kedua hal tersebut. Meskipun harga produk organik lebih tinggi, konsumen semakin menyadari konsekuensi negatif dari pertanian konvensional dan beralih untuk mengonsumsi produk organik (Pinna et al., 2014). Kedua, konsumen yang telah menyadari akan pentingnya kesehatan dan lingkungan tetapi tetap memilih mengonsumsi pangan konvensional dikarenakan harga pangan organik yang relatif mahal. Dalam hal ini perlu pemahaman dua aspek yang saling terkait, yaitu kesadaran konsumen dan kesediaan mereka untuk membayar (willingness to pay), yang dapat menentukan apakah masyarakat akan mengonsumsi produk organik atau tidak.

Beras yang merupakan komoditas makanan pokok utama di Indonesia memiliki harga lebih tinggi untuk jenis beras organik dibandingkan dengan jenis beras biasa. Harga eceran beras biasa sepanjang tahun 2018 berkisar antara Rp12.000 hingga Rp25.000 per kilogram (BPS, 2019) sedangkan harga beras organik di pasar berkisar antara Rp26.000 sampai Rp35.000 atau lebih per kilogram. Variasi harga ini disebabkan oleh berbagai faktor diantaranya jenis, kualitas, dan lokasi penjualan. Beras organik yang bersifat premium menyebabkan pemasarannya lebih spesifik, baik untuk target konsumen maupun tempat penjualannya. Untuk memperoleh beras organik salah satunya bisa didapatkan di supermarket, e-commerce, atau di ritel-ritel khusus yang menjual pangan organik.

Beras organik baik untuk kesehatan dan sudah tersedia di Warung Sehat 1000 Kebun selama kurang lebih 1,5 tahun. Namun, penjualan beras tersebut masih fluktuatif sehingga menyebabkan keuntungan yang diterima belum stabil. Tujuan dari penelitian ini adalah: 1) mengetahui nilai kesediaan membayar (willingness to pay) konsumen beras organik. 2) Mengetahui faktorfaktor yang berkaitan dengan kesediaan membayar (willingness to pay) konsumen beras organik.

Bertambahnya kepedulian dan kesadaran masyarakat terhadap kesehatan dan lingkungan, diharapkan mampu meningkatkan konsumen beras organik secara signifikan sehingga dapat dikonsumsi dan dijangkau oleh lebih banyak lagi kalangan masyarakat. Warung Sehat 1000 Kebun (W1000K) sebagai salah satu ritel khusus bahan pangan organik yang sudah menyediakan beras organik yang baik untuk kesehatan selama kurang lebih 1,5 tahun diharapkan lebih banyak dikenal masayarakat dan memiliki pelanggan yang tetap sehingga penjualan per periode bisa stabil yang menyebabkan keuntungan yang diterima pun akan stabil. Pada kenyatannya konsumen beras organik bertambah dalam jumlah yang tidak signifikan, beras organik hanya dikonsumsi oleh penderita penyakit yang mengharuskan mengkonsumsi makanan organik dan kalangan masyarakat yang sadar kesehatan serta lingkungan dan mampu membeli beras organik. Pada kenyataannya, W1000K baru mencakup konsumen di daerah Bandung dan pelanggannya pun masih bergantiganti sehingga penjualan bersifat fluktuatif yang menyebabkan keuntungan yang diterima belum stabil.

Berdasarkan hal tersebut, penelitian ini bertujuan untuk mengukur kesediaan untuk membayar (willingness to pay) dari konsumen beras organik dan menganalisis faktor-faktor yang berkaitan dengan kesediaan membayar dari konsumen beras organik. Dengan demikian, diharapkan hasil penelitian ini dapat dijadikan sebagai bahan pertimbangan oleh $\mathrm{W} 1000 \mathrm{~K}$ dalam menentukan harga beras organik, sehingga dapat membuka peluang untuk mendapatkan penerimaan yang lebih besar.

\section{METODE}

\section{LOKASI DAN WAKTU PENELITIAN}

Penelitian dilakukan pada konsumen beras organik di Warung Sehat 1000 Kebun yang bertempat di Arcamanik Bandung dan konsumen beras organik yang tergabung dalam Komunitas Organik Indonesia. Hal ini berdasarkan pertimbangan bahwa Warung Sehat 1000 Kebun adalah ritel khusus yang menjual produk organik termasuk didalamnya beras organik. Sedangkan Komunitas Organik Indonesia diambil berdasarkan pertimbangan kebutuhan data pembanding. 
Penelitian dilakukan dari bulan November 2019 Desember 2019.

\section{METODE PENENTUAN RESPONDEN}

Populasi dalam penelitian ini yaitu konsumen beras organik di Warung Sehat 1000 Kebun (W1000K) dan konsumen beras organik di beberapa tempat lain yang tergabung dalam Komunitas Organik Indonesia (konsumen umum). Populasi konsumen beras organik di W1000K dihitung berdasarkan jumlah konsumen yang berada di grup pelanggan Warung Sehat 1000 Kebun yaitu berjumlah 324 orang, menurut penuturan kepala warung diasumsikan bahwa 1/3 dari anggota grup tersebut pernah membeli beras organik. Sehingga populasi konsumen beras organik di Warung Sehat 1000 Kebun berjumlah 108 orang. Teknik sampling yang digunakan yaitu simple random sampling yaitu proses pengambilan sampel yang dilakukan dengan memberi kesempatan yang sama pada setiap anggota populasi untuk menjadi anggota sampel dan populasi dianggap homogen. Selanjutnya, penentuan jumlah responden atau sampel dilakukan berdasarkan perhitungan rumus Slovin, yaitu:

$$
n=\frac{N}{1+N\left(d^{2}\right)}
$$

Keterangan:

$\mathrm{N}=$ Ukuran sampel

$\mathrm{N}=$ Jumlah populasi

$d^{2}=$ Nilai presisi yang ditetapkan/interval keyakinan

Diketahui Populasi konsumen beras organik di Warung Sehat 1000 Kebun sebesar N = 108 orang dan tingkat presisi yang ditetapkan $10 \%$. Berdasarkan rumus tersebut diperoleh ukuran sampel (n) sebagai berikut:

$$
\begin{aligned}
& n=\frac{108}{1+1}=51,9 \\
& 08\left(0,1^{2}\right) \\
& n=52 \text { (dibulatkan) }
\end{aligned}
$$

Ukuran sampel yang didapatkan yaitu sebesar 52 orang. Alat pengumpulan data yang digunakan yaitu berupa kuesioner dan kuesioner tersebut dibagikan melalui grup pelanggan berupa google formulir. Pada kenyataannya, konsumen beras organik yang mengisi kuesioner tersebut berjumlah 18 orang.

Sementara itu, penentuan ukuran sampel untuk konsumen umum didasarkan pada teorema limit sentral, yang menyatakan statistik rata-rata mempunyai distribusi normal untuk ukuran sampel yang mendekati tak berhingga. Akan tetapi dalam prakteknya, teorema limit sentral telah dapat diterapkan untuk ukuran sampel minimal 30 (Agung, 2006). Maka dari itu, ukuran sampel konsumen beras organik di beberapa tempat lain berjumlah 30 orang dan pada kenyataannya peneliti mendapatkan responden sebanyak 33 orang.

\section{DATA DAN INSTRUMEN PENELITIAN}

Data yang digunakan dalam penelitian ini adalah data primer dan data sekunder. Data primer merupakan data yang diperoleh langsung dari hasil penyebaran kuesioner kepada konsumen beras organik yaitu berupa karakteristik konsumen, nilai kesediaan membayar beras organik, dan faktor-faktor yang berkaitan dengan kesediaan membayar beras organik. Sedangkan data sekunder diperoleh dari Badan Pusat Statistik, Dinas Tanaman Pangan dan Hortikultura Provinsi Jawa Barat dan berbagai sumber lainnya. Teknik pengumpulan data dilakukan melalui: 1) Studi Pustaka, dan 2) wawancara dengan panduan kuesioner.

\section{METODE PENGOLAHAN DAN ANALISIS DATA}

Analisis statistik deskriptif digunakan untuk menjawab tujuan penelitian mengenai faktor-faktor yang berkaitan dengan kesediaan membayar beras organik serta analisis contingent valuation method (CVM) untuk willingness to pay beras organik. tahap operasional yang dilakukan untuk mendapatkan nilai willingness to pay yaitu pertama membangun pasar hipotetik (setting up the hypothetical market), kedua menentukan nilai lelang willingness to pay (obtaining bids) berdasarkan harga produk yang diketahui oleh responden, dan ketiga menentukan dugaan nilai rataan willingness to pay.

1. Pasar Hipotetik

Pasar hipotetik termasuk didalamnya definisi beras organik, jenis beras organik dengan 
kriteria tertentu, dan ritel beras organik dalam penelitian ini yaitu Warung Sehat 1000 Kebun. Pasar hipotetik ini bertujuan untuk membangun persepsi konsumen dan membantu memahami deskripsi, jenis, merk, dan ukuran beras organik. Persepsi konsumen akan menciptakan minat atau kesediaan untuk membeli produk (Pardian, 2017).

\section{Menentukan nilai lelang WTP}

Fase ini dilakukan melalui survey dengan menggunakan kuesioner untuk mendapatkan nilai WTP (harga) nilai maksimum kesediaan membayar konsumen untuk beras organik. Nilai awal (titik awal) yang diambil adalah harga maksimum beras organik yang berlaku di Warung Sehat 1000 Kebun yaitu beras Pandan Wangi curah Rp. 26.000/kg, beras Menthik Susu curah Rp. 27.000/kg, beras Merah curah Rp.27.000/kg, beras Coklat curah Rp. 27.000/kg, beras Hitam curah Rp. 35.000/kg.

\section{Menghitung estimasi nilai rata-rata WTP}

Nilai ini dihitung berdasarkan nilai yang diperoleh pada tahap sebelumnya. Estimasi nilai rata-rata WTP dapat dihitung dengan rumus (Setiyadi, 2017):

$$
E W T P=\sum_{i=0}^{n} W_{i} \cdot P f_{i}
$$

Keterangan:

EWTP = Perkiraan rata-rata kesediaan membayar konsumen beras organik (Rupiah).

Wi = Nilai dari kesediaan membayar (Rupiah).

Pfi = Frekuensi i-relatif dari kelas WTP ke-i.

$\mathrm{n} \quad=$ Jumlah kelas WTP.

$\mathrm{i} \quad=\operatorname{Responden}-\mathrm{i}(\mathrm{i}=1,2, ., \mathrm{n})$

\section{METODE FAKTOR-FAKTOR YANG BERKAITAN DENGAN KESEDIAAN MEMBAYAR BERAS ORGANIK}

Pemilihan faktor-faktor yang akan diteliti didasarkan pada faktor yang secara signifikan memengaruhi kesediaan membayar beras organik pada penelitian terdahulu, yaitu:

1. Keamanan pangan, kesehatan, pengetahuan, dan lingkungan (Li, 2019).

2. Pengetahuan sertifikasi organik (Andito, 2018).

3. Harga hedonic beras dan residu pestisida (Utami, 2011).
4. Gaya hidup, peduli lingkungan, rasa beras, dan akses memperoleh beras (Trisnawati, 2015).

5. Kualitas produk, harga produk, keamanan produk, dan gaya hidup (Febritas, 2017).

6. Harga beras dan kemasan ergonomis (Setiyadi, 2017).

\section{HASIL DAN PEMBAHASAN}

\section{KARAKTERISTIK KONSUMEN BERAS ORGANIK}

Berdasarkan hasil survey, konsumen beras organik baik di Warung Sehat 1000 Kebun maupun di beberapa tempat lain didominasi oleh perempuan (84\%) dan berada pada kategori usia dewasa yaitu antara 26-45 tahun. Konsumen tersebut telah menempuh jenjang pendidikan yang tinggi mulai dari diploma sampai S2 (73\%). Konsumen beras di W1000K didominasi oleh ibu rumah tangga dengan pendapatan diatas Rp7.000.000/ bulan sedangkan di tempat lain didominasi oleh wiraswasta dan mahasiswa dengan pendapatan Rp1.000.000-Rp3.000.000/ bulan.

\section{WILLINGNESS TO PAY BERAS ORGANIK}

Berdasarkan hasil survey, konsumen bersedia membayar beras organik dengan harga yang telah ditentukan. Analisis Willingness to pay beras organik dilakukan menggunakan pendekatan CVM (Contingent Valuation Method) dengan tahapan sebagai berikut:

\section{Hipotesis Pasar}

Konsumen beras organik diberikan informasi mengenai pengertian beras organik dan keunggulan-keunggulan beras organik dibandingkan dengan beras lain dan nilai positif bagi lingkungan sebagai hasil dari mengonsumsi beras organik. Tujuan dari informasi tersebut yaitu memberikan gambaran umum kepada konsumen sehingga dapat menjadi pertimbangan untuk memutuskan berapa harga yang bersedia dibayarkan oleh konsumen untuk beras organik yang dijual di Warung Sehat 1000 Kebun. Pasar hipotetik tersebut yaitu: "Beras organik merupakan beras yang berasal dari pertanian dengan teknik budidaya organik atau tanpa memakai pupuk kimia, pestisida kimia, hormon, bahan pemutih, dan obat-obatan sehingga lebih aman untuk 
dikonsumsi. Dalam budidayanya beras organik menggunakan bibit lokal dan pupuk yang berasal dari kotoran hewan maupun kompos. Selain itu, beras organik tidak mengandung bibit yang dihasilkan dari rekayasa genetika dan tidak memanfaatkan teknologi radiasi untuk mengawetkan produknya. Beras organik juga dianggap sebagai alternatif untuk memelihara lingkungan dan disertifikasi oleh lembaga sertifikasi. Beras organik yang dijual di Warung Sehat 1000 Kebun yaitu menthik susu, pandan wangi, beras merah, beras coklat, dan beras hitam dengan minimal pembelian 250 gram".

\section{Nilai Lelang WTP}

Tahapan ini dilakukan untuk memperoleh nilai yang sebenarnya bersedia konsumen bayarkan untuk membeli beras organik di Warung Sehat 1000 Kebun. Teknik yang digunakan untuk mendapatkan nilai lelang dalam penelitian ini adalah teknik pertanyaan terbuka (open ended). Nilai terendah dan tertinggi dari kesediaan konsumen membayar untuk masing-masing jenis beras adalah sebagai berikut: beras Pandan Wangi yaitu Rp27.000 dan Rp30.000, Beras Menthik Susu yaitu Rp23.000 dan Rp32.000, Beras Merah yaitu Rp20.000 dan Rp30.000, Beras Coklat yaitu
Rp27.000 dan Rp35.000, dan Beras Hitam yaitu Rp27.500 dan Rp35.000. Nilai tersebut merupakan nilai maksimal dari kesediaan konsumen untuk membayar kemudian diurutkan dari nilai yang paling rendah hingga paling tinggi.

\section{Nilai Rataan WTP}

Dugaan nilai rataan WTP responden di Warung Sehat 1000 kebun terhadap harga maksimum untuk masing-masing jenis beras diperoleh berdasarkan nilai WTP yang diberikan responden dengan jumlah responden yang bersedia membayar dengan harga tersebut (Tabel 2). Berikut hasil nilai rataan WTP untuk masingmasing jenis beras:

1) Beras Pandan Wangi

Hasil nilai rataan WTP responden untuk beras Pandan Wangi menunjukkan angka Rp28.500/kg untuk konsumen W1000K dan Rp29.813/kg untuk konsumen di beberapa tempat lain. Nilai ini lebih tinggi jika dibandingkan dengan harga yang ditawarkan oleh pihak Warung Sehat 1000 Kebun, yaitu Rp26.000/kg. Nilai rataan tersebut mengindikasikan bahwa adanya surplus konsumen karena nilai WTP yang diinginkan responden

Tabel 2. Distribusi Nilai (Harga) WTP Beras Organik

\begin{tabular}{|c|c|c|c|c|c|}
\hline Jenis Beras & $\begin{array}{l}\text { Nilai WTP } \\
\text { (Rp) }\end{array}$ & $\begin{array}{l}\text { Jumlah } \\
\text { responden } \\
\text { (orang) }\end{array}$ & $\begin{array}{c}\text { Frekuensi } \\
\text { Relatif (Pfi) }\end{array}$ & $\begin{array}{l}\text { Mean WTP } \\
\text { (Rp/orang) }\end{array}$ & $\begin{array}{c}\text { Total WTP } \\
\text { (Rp/orang) }\end{array}$ \\
\hline \multirow{3}{*}{ Pandan Wangi } & 27.000 & 1 & 0,5 & 13,500 & 27.000 \\
\hline & 30.000 & 1 & 0,5 & 15.000 & 30.000 \\
\hline & Total & 2 & 1 & 28.500 & $\mathbf{5 7 . 0 0 0}$ \\
\hline \multirow{5}{*}{ Menthik Susu } & 23.000 & 1 & 0,11 & 2.556 & 23.000 \\
\hline & 27.000 & 3 & 0,33 & 9.000 & 81.000 \\
\hline & 30.000 & 4 & 0,44 & 13.333 & 120.000 \\
\hline & 32.000 & 1 & 0,11 & 3.556 & 32.000 \\
\hline & Total & 9 & 1 & 28.444 & 256.000 \\
\hline \multirow{5}{*}{ Merah } & 20.000 & 1 & 0,17 & 3.333 & 20.000 \\
\hline & 25.000 & 1 & 0,17 & 4.167 & 25.000 \\
\hline & 27.000 & 1 & 0,17 & 4.500 & 27.000 \\
\hline & 30.000 & 3 & 0,50 & 15.000 & 90.000 \\
\hline & Total & 6 & 1 & 27.000 & 162.000 \\
\hline \multirow{4}{*}{ Coklat } & 27.000 & 3 & 0,6 & 16.200 & 81.000 \\
\hline & 30.000 & 1 & 0,2 & 6.000 & 30.000 \\
\hline & 35.000 & 1 & 0,2 & 7.000 & 35.000 \\
\hline & Total & 5 & 1 & 29.200 & 146.000 \\
\hline \multirow{4}{*}{ Hitam } & 27,500 & 1 & 0,25 & 6.875 & 27.500 \\
\hline & 30.000 & 1 & 0,25 & 7.500 & 30.000 \\
\hline & 35.000 & 2 & 0,5 & 17.500 & 70.000 \\
\hline & Total & 4 & 1 & 31.875 & 127.500 \\
\hline
\end{tabular}

Sumber: Hasil Survey (2019) 
lebih tinggi sebesar Rp2.500-Rp3.813 dibandingkan dengan harga yang ditawarkan.

2) Beras Menthik Susu

Hasil nilai rataan WTP responden untuk beras Menthik Susu menunjukkan angka Rp28.444/kg untuk konsumen W1000K dan Rp28.333/kg untuk konsumen di beberapa tempat lain. Nilai ini lebih tinggi jika dibandingkan dengan harga yang ditawarkan oleh pihak Warung Sehat 1000 Kebun, yaitu Rp27.000/kg. Nilai rataan tersebut mengindikasikan bahwa adanya surplus konsumen karena nilai WTP yang diinginkan responden lebih tinggi sebesar Rp1.333-Rp.1.444 dibandingkan dengan harga yang ditawarkan.

3) Beras Merah

Hasil nilai rataan WTP responden untuk beras Merah menunjukkan angka Rp27.000/kg untuk konsumen W1000K dan Rp32.238/kg untuk konsumen di beberapa tempat lain. Nilai rataan tersebut mengindikasikan bahwa harga yang ditawarkan sudah sesuai dengan harga yang sedia konsumen bayarkan konsumen W1000K dan lebih tinggi untuk konsumen di beberapa tempat lain, jika dibandingkan dengan harga yang ditawarkan oleh pihak Warung Sehat 1000 Kebun yaitu Rp27.000/kg.

4) Beras Coklat

Hasil nilai rataan WTP responden untuk beras Coklat menunjukkan angka Rp29.200/kg untuk konsumen W1000K dan Rp32.875/kg untuk konsumen di beberapa tempat lain. Nilai ini lebih tinggi jika dibandingkan dengan harga yang ditawarkan oleh pihak Warung Sehat 1000 Kebun yaitu Rp27.000/kg. Nilai rataan tersebut mengindikasikan bahwa adanya surplus konsumen karena nilai WTP yang diinginkan responden lebih tinggi sebesar Rp2.200 Rp.5.875 dibandingkan dengan harga yang ditawarkan.

5) Beras Hitam

Hasil nilai rataan WTP responden untuk beras Hitam menunjukkan angka Rp31.875/kg untuk konsumen W1000K dan Rp32.083/kg untuk konsumen di beberapa tempat lain. Nilai ini lebih rendah jika dibandingkan dengan harga yang ditawarkan oleh pihak Warung Sehat 1000 Kebun, yaitu Rp35.000/kg. Nilai rataan tersebut mengindikasikan bahwa ada- nya defisit konsumen karena nilai WTP yang diinginkan responden lebih rendah daripada nilai WTP rata-rata, yaitu sebesar Rp3.125Rp3.917. Hal tersebut dikarenakan konsumen masih mempertimbangkan biaya jika harga bahan pangan pokok yang akan dikonsumsi setiap hari terlalu tinggi.

Perbedaan nilai kesediaan membayar antara konsumen beras di Warung Sehat 1000 Kebun dan di beberapa tempat lain disebabkan oleh beberapa faktor yaitu pertama dari domisili konsumen, konsumen beras di Warung Sehat 1000 Kebun berasal dari Bandung sedangkan konsumen di beberapa tempat lain tersebar di beberapa daerah yaitu Bandung, Jatinangor, Surabaya, Semarang, Yogyakarta, Tasikmalaya, Pamulang, BSD, Jakarta, Bogor, Depok, dan Tanggerang, serta membeli beras organik di tempat yang berbeda-beda. Selain itu, berdasarkan hasil survey mayoritas konsumen beras di Warung Sehat 1000 Kebun memiliki pendapatan lebih dari Rp7.000.000/ bulan sedangkan mayoritas konsumen di tempat lain memiliki pendapatan Rp1.000.000Rp3.000.000/bulan.

\section{FAKTOR-FAKTOR YANG BERKAITAN DENGAN WILLINGNESS TO PAY KONSUMEN BERAS ORGANIK}

Berikut beberapa faktor yang berkaitan dengan kesediaan membayar konsumen beras organik (Tabel 3):

\section{Kesehatan}

Berdasarkan hasil survey, sebanyak 72\% konsumen W1000K dan 64\% konsumen umum sangat setuju bahwa beras organik baik untuk kesehatan. Kesehatan merupakan motif penting bagi pembelian produk organik dengan harapan konsumen mendapatkan efek baik bagi kesehatan (Xie, 2015). Pernyataan tersebut didukung juga oleh hasil penelitian (Schobesberger, 2007) bahwa alasan utama konsumen membeli produk organik yaitu konsumen mengharapkan dampak positif bagi kesehatan, dengan ketidakhadiran residu pestisida dan juga produk organik merupakan produk ramah lingkungan. Meskipun kesehatan menjadi faktor utama dalam membeli produk organik, namun tidak ada literatur yang mempunyai bukti kuat bahwa makanan organik 
Tabel 3. Rekapitulasi Tanggapan Faktor-Faktor yang Berkaitan dengan WTP

\begin{tabular}{|c|c|c|c|c|c|c|c|c|c|c|c|}
\hline \multirow{2}{*}{ Faktor Nilai } & \multicolumn{2}{|c|}{ (1) } & \multicolumn{2}{|c|}{ (2) } & \multicolumn{2}{|c|}{ (3) } & \multicolumn{2}{|c|}{ (4) } & \multicolumn{2}{|c|}{ (5) } & \multirow{2}{*}{ Total } \\
\hline & (A) & (B) & (A) & (B) & (A) & (B) & (A) & (B) & (A) & (B) & \\
\hline Keamanan pangan & 0 & 1 & 0 & 0 & 2 & 3 & 9 & 13 & 7 & 16 & 51 \\
\hline Kesehatan & 0 & 0 & 0 & 0 & 0 & 2 & 5 & 10 & 13 & 21 & 51 \\
\hline Kualitas & 0 & 1 & 0 & 0 & 3 & 4 & 10 & 20 & 5 & 8 & 51 \\
\hline kemasan & 0 & 0 & 2 & 1 & 4 & 17 & 6 & 9 & 6 & 6 & 51 \\
\hline Akses & 0 & 0 & 0 & 2 & 1 & 10 & 7 & 12 & 10 & 9 & 51 \\
\hline Harga & 0 & 1 & 1 & 1 & 3 & 12 & 10 & 13 & 4 & 6 & 51 \\
\hline Pengetahuan & 0 & 0 & 0 & 1 & 1 & 3 & 12 & 14 & 5 & 15 & 51 \\
\hline Lingkungan & 0 & 1 & 2 & 0 & 2 & 6 & 8 & 10 & 6 & 16 & 51 \\
\hline Gaya hidup & 2 & 7 & 3 & 8 & 2 & 6 & 9 & 5 & 2 & 7 & 51 \\
\hline Pelayanan & 0 & 0 & 0 & 0 & 1 & 11 & 10 & 12 & 7 & 10 & 51 \\
\hline
\end{tabular}

Keterangan:
(1) = Sangat Tidak Setuju
(4) = Setuju
(2) = Tidak Setuju
(5) = Sangat Setuju
(A) = Konsumen Warung Sehat 1000 Kebun
(3) = Cukup Setuju
(B) = Konsumen di beberapa tempat lain

Sumber: Hasil Survey(2019)

secara signifikan lebih bergizi daripada makanan konvensional. Konsumsi makanan organik dapat mengurangi paparan residu pestisida dan bakteri yang resisten terhadap antibiotik (Smith, et al., 2012)

\section{Keamanan Pangan}

Berdasarkan hasil survey, Sebagian konsumen $\mathrm{W} 1000 \mathrm{~K}$ setuju bahwa beras organik yang dijual di W1000K bebas dari bahan kimia, dengan presentase jawaban sebesar 50\%. Dan sebanyak $48 \%$ konsumen sangat setuju bahwa beras yang mereka konsumsi bebas dari bahan kimia. Mayoritas konsumen membeli produk organik dikarenakan tidak mengandung bahan kimia seperti pestisida dan organisme yang telah mengalami perubahan genetic (Xie, 2015). Sebagian masyarakat mengonsumsi makanan tidak hanya sekedar untuk pemenuhan kebutuhan dasar saja, tetapi sebagai pemenuhan kebutuhan kesehatan, adapun tingkat keamanan merupakan salah satu pertimbangan dalam pemilihan makanan (Sinaga, 2010).

\section{Dampak terhadap Lingkungan}

Berdasarkan hasil survey, 44\% konsumen W1000K setuju bahwa mereka mengonsumsi beras organik karena telah mengetahui dampaknya terhadap lingkungan. Dan sebanyak 48\% konsumen sangat setuju bahwa mereka mengonsumsi beras organik karena telah mengetahui dampaknya terhadap lingkungan. Konsumen yang berpikiran politis/etis memiliki pertimbangan saat membeli makanan organik yaitu adanya manfaat lingkungan dan kesejahteraan hewan (Xie, 2015).

\section{Pengetahuan Mengenai Beras Organik}

Berdasarkan hasil survey, $67 \%$ konsumen W1000K setuju bahwa mereka mengonsumsi beras organik karena telah mengetahui segala informasi mengenai beras organik. Dan sebanyak $45 \%$ konsumen umum sangat setuju bahwa mereka mengonsumsi beras organik karena telah mengetahui segala informasi mengenai beras organik.

Pengetahuan terhadap beras organik merupakan salah satu variabel signifikan terhadap kesediaan konsumen untuk membayar beras organik, pengetahuan konsumen yang terbatas tentang produk organik dapat memengaruhi mereka untuk membeli produk organik (Xie, 2015). Pengetahuan dan informasi juga menyebabkan konsumen mengubah kecenderungan mereka terhadap produk organik (Klashami, 2012).

\section{Akses dalam Mendapatkan Beras}

Berdasarkan hasil survey, 56\% konsumen W1000K sangat setuju bahwa beras organik yang dijual di W1000K mudah untuk didapatkan karena sebagian besar alasan konsumen membeli beras organik di W1000K karena dekat dengan rumah. Dan sebanyak 36\% konsumen setuju bahwa beras yang mereka konsumsi mudah untuk didapatkan.

$86,9 \%$ dari total responden menyatakan bahwa mereka membutuhkan lebih banyak 
informasi mengenai produk makanan organik dari media, terutama dimana mereka dapat membeli beras organik. Hanya $46,9 \%$ pembeli organik yang puas dengan berbagai produk organik yang tersedia di pasar karena produk makanan organik jarang ditemui di pasar lokal, sebagian besar hanya ditemukan di toko khusus organik atau supermarket besar dan juga variasi makanan organik lebih sedikit (Xie, 2015).

\section{Pelayanan}

Berdasarkan hasil survey, 56\% konsumen setuju bahwa pelayanan di W1000K memuaskan dan sebanyak 36\% konsumen setuju bahwa pelayanan di tempatnya memberi beras organik memuaskan. Penelitian yang dilakukan oleh Alfredo D.S di D'Stupid Baker Surabaya menyatakan bahwa kualitas pelayanan berpengaruh positif dan signifikan terhadap keputusan pembelian konsumen. Kualitas pelayanan adalah tingkat keunggulan yang diharapkan dan penanganan atas tingkat

Keunggulan tersebut untuk memenuhi keinginan konsumen. Apabila pelayanan yang diterima sesuai dengan yang diharapkan, maka kualitas pelayanan dianggap baik dan memuaskan. Jika pelayanan yang diterima melampuai harapan konsumen, makan kualitas pelayanan dianggap ideal. Sebaliknya jika pelayanan yang diterima rendah dari yang diharapkan, makan kualitas pelayanan dianggap buruk (Tjioptono, 2009).

\section{Kualitas Beras}

Berdasarkan hasil survey, Konsumen W1000K maupun konsumen umum setuju bahwa beras organik yang mereka konsumsi memiliki kualitas yang baik dengan presentase jawaban sebesar 56\% dan 61\%. 65\% konsumen produk organik berpikir bahwa produk organik memiliki rasa yang lebih enak dan juga lebih segar, serta konsumen produk organik menyatakan bahwa produksi makanan organik sama dengan pertanian alami atau tradisional (Xie, 2015). Konsumen beras kemasan di jember juga lebih mengutamakan faktor kualitas yang meliputi ukuran butiran, bentuk butiran, dan tekstur saat membeli beras kemasan. Hal tersebut dikarenakan konsumen menganggap bahwa produk beras dalam kemasan dikatakan berkualitas jika telah diketahui atau dirasakan adanya nilai lebih pada beras (Aji \& Widodo, 2010). Menurut Rasmikayati dkk (2020), kualitas produk berpengaruh signifikan terhadap kepuasan konsumen. Lebih jauh lagi, merujuk kepada Natawidjaja dkk. (2017) bahwa kualitas beras merupakan salah satu faktor yang berpengaruh secara signifikan dalam menentukan willingness to pay.

\section{Kemasan Beras}

Berdasarkan hasil survey, 33\% konsumen setuju dan 33\% konsumen sangat setuju bahwa kemasan beras organik di W1000K menarik. Serta sebanyak 52\% konsumen umum cukup setuju bahwa kemasan beras yang dibelinya menarik. Kemasan produk berpengaruh terhadap faktorfaktor yang memengaruhi nilai WTP, semakin tinggi tingkat ergonomis kemasan maka nilai Willingness to pay akan semakin meningkat. Responden menyatakan bahwa kemasan ergonomis memiliki gambaran (image) yang baik sehingga mereka bersedia untuk membayar dengan harga yang lebih tinggi (Xie, 2015).

Adapun persepsi konsumen beras dalam kemasan bermerk di Jember masih terbatas pada tahap estetika kemasan dari produk tersebut yang lebih mengarah ke penampilan dari kemasan dari pada kualitas dari beras yang ada didalamnya. Hal ini menandakan bahwa pembentukan persepsi konsumen terhadap beras dalam kemasan bermerk umumnya masih berangkat dari estetika dan bukan dari merk yang menjamin kualitas (Aji \& Widodo, 2010).

\section{Harga}

Berdasarkan hasil survey, Konsumen W1000K maupun konsumen umum setuju bahwa harga beras organik yang mereka beli terjangkau dengan presentase jawaban sebesar 56\% dan 39\%. Berdasarkan penelitian Natawidjaja dkk. (2017) mayoritas konsumen beras premium mengatakan bahwa mereka berhenti untuk membeli produk makanan organik karena harga yang jauh lebih tinggi dibandingkan dengan yang konvensional. Studi ini juga menunjukkan bahwa tingkat pendapatan keluarga merupakan faktor penting untuk mempengaruhi keputusan pembelian organik. 
Hasil ini sesuai dengan penelitian lain yang menunjukkan bahwa konsumen di negara-negara yang relatif makmur lebih cenderung membeli makanan organik daripada konsumen di negara lain (Hjelmar, 2011). Variabel harga beras organik berpengaruh nyata terhadap permintaan beras organik. Jika harga beras organik meningkat sebesar 1\% maka akan menurunkan jumlah permintaan beras organik sebesar $16,475 \%$ (Risty dan Rahmanta, 2013). Berdasarkan analisis regresi, ketika harga beras organik meningkat sebesar $1 \%$, maka kesediaan membayar akan naik sebesar 7,84\%. Harga merupakan faktor penting dan sangat sensitif terhadap kesediaan konsumen untuk membayar. Harga tinggi mencerminkan kualitas produk (Setiyadi, 2017).

\section{Gaya Hidup}

Berdasarkan hasil survey, Sebagian (50\%) konsumen W1000K setuju bahwa mereka mengonsumsi beras organik sebagai gaya hidup. Sedangkan untuk konsumen umum tidak setuju bahwa mereka mengonsumsi beras organik sebagai gaya hidup, dengan presentase sebanyak 24\%. Lebih dari setengah responden pembeli produk organik menyatakan bahwa mereka membeli makanan organik untuk mengejar gaya hidup sehat (Xie, 2015).

Gaya hidup memiliki pengaruh yang dominan dengan hasil sebesar 33\%. Gaya hidup sangat dipengaruhi oleh lingkungan konsumen baik secara geografis maupun demografis (terkait pendapatan, usia, serta tingkat pendidikan) dalam memengaruhi perilaku konsumen untuk membangun sikap awareness terhadap pola hidup sehatnya (Febritas, 2017). Konsumen akan bersikap setia untuk terus menggunakan suatu produk apabila mereka telah percaya pada manfaat yang diberikan oleh produk tersebut (Rasmikayati dkk., 2017). Merujuk pada pernyataan tersebut produk beras organik masih akan terus menambah pelanggan setianya dengan semakin banyaknya konsumen yang mulai merasakan manfaat dari beras organik dari waktu ke waktu.

\section{SIMPULAN DAN SARAN}

\section{SIMPULAN}

1. Kesediaan membayar konsumen untuk Beras Pandan Wangi, Beras Menthik Susu, Beras Merah, Beras Coklat di W1000K lebih tinggi sebesar 0\%-10\% dan 5\%-22\% di beberapa tempat lain. Sedangkan untuk beras hitam lebih rendah 9\%-11\% dari harga yang ditawarkan.

2. Faktor-faktor yang berkaitan dengan kesediaan membayar konsumen beras organik adalah kesehatan (67\%), keamanan pangan (45\%), dampak terhadap lingkungan (43\%), pengetahuan mengenai beras organik (39\%), kemudahan akses dalam mendapatkan beras (37\%), pelayanan (33\%), kualitas beras (25\%), kemasan beras (24\%), harga (20\%), dan gaya hidup (18\%).

\section{SARAN}

1. Menyertakan informasi yang menandakan adanya jaminan bahwa beras yang dijual adalah beras organik asli. Dapat berupa sertifikat beras organik dari supplier. Sertifikat tersebut dapat disajikan di sebelah display beras di W1000K, sebagai sarana edukasi pasar bagi konsumen maupun sebagai bahan untuk promosi di media sosial, sehingga dapat meningkatkan kepercayaan konsumen beras W1000K dan menarik minat calon konsumen baru. Dapat disertakan pula cerita dibalik beras organik tersebut di dalam kemasan seperti: siapa yang menanam, dimana beras ditanam, dampak pertanian organik bagi lingkungan secara berkelanjutan, serta manfaat apa yang terkandung pada beras tersebut atau menyertakan visi dan misi dai W1000K sehingga dapat meningkatkan value dari beras orgnaik tersebut.

2. Mengkaji kembali harga jual beras hitam organik karena menurut hasil survey kesediaan membayar konsumen W1000K untuk beras hitam organik sebesar Rp31.875/kg dan di beberapa tempat lain sebesar Rp31.083/kg, sedangkan harga jual saat ini Rp35.000/kg. 
3. Menjual beras dengan kriteria bebas dari hama dan tidak berbau, beras yang dijual adalah beras segar yang baru dipanen untuk menjaga kandungan gizi beras, menjaga kualitas beras agar tidak merubah rasa dan tekstur. Selanjutnya menyediakan kesamasan yang reusable. Beberapa hal tersebut sesuai dengan peningkatan kualitas yang diharapkan oleh konsumen.

\section{DAFTAR PUSTAKA}

Aji, J. M., \& Widodo, A. (2010). Perilaku Konsumen Pada Pembelian Beras Bermerk Di Kabupaten Jember Dan faktor Yang Mempengaruhinya. Fakultas pertanian Universitas Jember J-SEP Vol 4 No. 3 November 2010, 13-18.

Andito, F. (2018). Faktor-Faktor yang Mempengaruhi Kesediaan Membayar Lebih Konsumen pada Beras Bersertifikat Organik di Pasar Modern di Kota Medan (Kasus: Supermarket Brastagi).

Barkley, A. (2002). Organic Food Growth: Producer Profits and Corporate Farming. Presentation at the Risk and Profit Conference. Dept. of Agricultural Economics, Kansas State University, Manhattan, Kansas.

BPS. (2019). Harga Beras 2010-2019. Badan Pusat Statistik.

BPS, K. (2015). Statistik Daerah Kecamatan Arcamanik 2015. 1-5.

Febritas, R. R. (2017). Analisis Kesediaan Membayar (Willingness to Pay) Beras Organik (Studi Kasus: Gelael Signature Di Kota Makassar). Skripsi.

FIBL, \& International, I. O. (2017). The World of organic agriculture Statistics \& emerging trends 2017.

Gil, J. M., Gracia, A., \& Sanchez, M. (2001). Market Segmentation and Willingness to pay for Organic Products in Spain. International Food and Agribusiness Management Review 3, 207226.

Haghjou. (2013). Factors Affecting Consumers' Potential Willingness to pay for Organic Food
Products in Iran: Case Study of Tabriz. Journal of Agricultural Science and Technology 15(2), 191-202.

Hjelmar, U. (2011). Consumers' purchase of organic food products: a matter of convenience and reflexive practices. , Appetite, Vol. 56 No. 2, pp. 336-344.

Klashami, M., Heydari, M., \& Kazaerani, H. (2012). Investigasting consumer's WTP for organic chicken in Iran. International Journal of Agricultural Management and Development 2(4), 235-241.

Natawidjaja, R. S., Sulistiowaty, L., Kusno, K., Aryani, D., \& Rachmat, B. (2017). Analisis Preferensi Kepuasan dan Kesediaan Konsumen Membayar Beras di Kota Bandung. Diakses melalui: http://repository.unsri.ac.id/10520/.

Li, R. (2019). Consumers' Willingness to Pay for Organik Foods in China: Bibliometric Review for an Emerging Literature. International Jurnal of enviromental research and public healt.

Pardian, P. (2017, 6(3)). Persepsi dan Minat Petani Muda dalam Budidaya Sayuran Swiss Chard Organik. Dharmakarya, http://journal.unpad.ac.id/dharmakarya/ar ticle/view/14817.

Pinna, M., Del Chiappa, G., \& Velcovska, S. (2014, January). The food quality labels: Awareness and willingness to pay in the context of Italy. In Proceedings from the XII International Conference Marketing Trends, Paris-Venice: Paris-Marketing Trends Association.

Rasmikayati, E., Pardian, P., Hapsari, H., Ikhsan, R. M., \& Saefudin, B. R. (2017). Kajian Sikap dan Perilaku Konsumen dalam Pembelian Kopi Serta Pendapatnya terhadap Varian Produk dan Potensi Kedainya. Mimbar Agribisnis: Jurnal Pemikiran Masyarakat Ilmiah Berwawasan Agribisnis, 3(2), 117-133. DOI: http://dx.doi.org/10.25157/ma.v3i2.563.

Rasmikayati, E., Saefudin, B. R., Karyani, T., Kusno, K., \& Rizkiansyah, R. (2020). Analisis Faktor dan Tingkat Kepuasan Ditinjau dari Kualitas Produk dan Pelayanan pada Konsumen Sayuran Organik Di Lotte Mart Kota Bandung. Mimbar Agribisnis: Jurnal Pemikiran Masyarakat Ilmiah Berwawasan 
Agribisnis, 6(1), 351-364. Diakses melalui: https://jurnal.unigal.ac.id/index.php/mimb aragribisnis/article/view/3219.

Risty, C. T., \& Rahmanta Iskandarini, G. (2013). Elastisitas Permintaan Beras Organik di Kota Medan. Jornal on Social Economic of Agriculture And Agribusiness, 2(2).

Santoso, I., \& Fitryani, R. (2016). Green packaging, green product, consumer perception, and purchasing interest (in Indonesian). Jurnal Ilmu Keluarga dan Konsumen 9(2), 147-158.

Schobesberger, B. R., Darnhofer, I., Somsook, S., \& Vogl, C. R. (2007). Consumer perceptions of organic foods in Bangkok, Thailand. Elsevier. Food Policy 33 (2008), 112-121.

Setiyadi, H. (2017). Consumer Willingness to pay of Organik Rice and The Factors which Affected in Pontianak. Ilmu Pertanian (agriculltural science) Vol.1 No. 3.

Silalahi, N. E., Salmiah, \& Jufri, M. (2013). Tingkat Konsumsi dan Pola Konsumsi Beras Masyarakat di Kota Medan.

Sinaga, I. M. (2010). Analisis sikap, Persepsi Konsumen dan Rentang Harga pada Beras Organik SAE (Sehat Aman Enak) pada Gapoktan Silih Asih Desa Ciburuy Kabupaten Bogor Jawa Barat. Skripsi. Institut Pertanian Bogor. Bogor.

Smith, S. C., Brangdeau, M. L., Hunter, G. E., Bavinger, J. C., Pearson, M., Eschbach, P. J., \& Bravata, D. M. (2012). Are Organic Foods Safer or Healthier than conventional alternatives? Annals of Internal Medicine, 157(5), 348. Elsevier.

Thio, S. (2012). Persepsi Konsumen Terhadap Makanan Organik di Surabaya. Jurnal Penelitian Universitas Petra. Program Manajemen Perhotelan, Fakultas Ekonomi, Universitas Kristen Petra.

Tjioptono, F. (2009). Strategi Pemasaran Jasa. Yogyakarta: Andi.

Trisnawati, N. M. (2015). Faktor-faktor yang mempengaruhi permintaan konsumen.

Utami, D. P. (2011). Analisis Pilihan Konsumen Dalam Mengkonsumsi Beras Organik Di Kabupaten Sragen.
Xie, B., Wang, L., Yang, H., Wang, Y., \& Zhang, M. (2015). Consumer perceptions and attitudes of organic food products in Eastern China. British Food Journal, Vol. 117 Iss 3 pp. 1105 1121. 